\title{
Effect of Syrian Sumac Extract on Stability of Rice Bran oil And Canola oil
}

\author{
*Zenab Mostafa Mosa. ${ }^{* * A}$ Alshimaa Abdalla Hafez (specially education). \\ **Ereny Wilson Nagib \\ *Assistant lecturer Nutrition and Food Sciences, Home economics Dept., Fac. \\ of Education. Ain-Shams University. \\ ** lecturer Nutrition and Food Sciences, Home Economics Dept., Fac. of \\ Education. Ain-Shams University.
}

ABSTRACT

The antioxidants activities of sumac extract at various concentrations were evaluated in natural rice bran oil and canola oil stored at $65^{\circ} . \mathrm{C}$, for 35 days. The concentrations of extracts added into oil were $0.1 \%, 0.3 \%$ and $0.5 \%$. Antioxidants effect was determined by the measurement of peroxide value. In addition determine the fatty acid and rancidity of fats in the rice bran oil and canola oil proximate composition and active groups of sumac powder. The results indicated that the mean gross rancidity of fats of rice bran oil was $1 \%$, $3.7 \%, 205 \%$ and $0.8 \%, 5.58 \%, 202 \%$ of canola oil. The percentage of saturated fatty acids of rice bran oil was $16.73 \%$ and $11.70 \%$, respectively which was higher than the canola oil (3.93\% and $12.64 \%$ respectively). On the other hand the percentage of Poly Unsaturated Fatty Acid of of rice bran oil $(30.17 \%$ and $2.14 \%$, respectively) which were lower than the canola oil $(30.71 \%$ and $15.40 \%$ respectively). Extract at $0.5 \%$ in the rice bran oil after 14 into 35 days of storage had better antioxidant activity $(12.04 \%, 15.22 \%, 17.3 \%$ and $21.46 \%)$ than the control sample. On the other hand, extract at $0.5 \%$ in the canola oil had better antioxidant activity except for after 14 and 35 days of storage. The rate of inhibition of autoxidation in the rice bran oil and canola oil increases by increasing the concentration of extracts of sumach after 35 days of storage. On the other hand, the percentage rate of inhibition of autoxidation in the rice bran oil due to the presence of total natural antioxidants was $1.25 \%$ but it was $3.75 \%$ in the canola oil. The results showed that Sumac extract is also promising as a source of natural antioxidants.

Key words: Sumac- Antioxidant Activities- Rice Bran oil - Canola oil

\section{Introduction}

Sumac is the common name for a genus (Rhus) that contains over 250 individual species of flowering plants in the family Anacardiaceae (USDA ,2007). In general, sumac can grow in non-agriculturally viable regions and various species have been used by indigenous people for medicinal and other 
purposes, suggesting potential for commercializing the bioactivity of these plants without competing for food production land uses (Van Wyk and Win ,2004). For example, Rhus glabra (Smooth sumac) is traditionally used by native peoples of North America in the treatment of bacterial diseases such as syphilis, gonorrhea, dysentery and gangrene (Erichsen-Brown ,1989).

The fruits of Rhus coriaria (Sicilian sumac) are commonly used as a condiment in the Mediterranean region and Middle East. R. coriaria is also used as a herbal remedy in traditional medicine due to its analgesic, antidiarrhetic, antiseptic, anorexic and antihypergylcaemic properties (Rayne and Mazza ,2007).

However, the extract of $\mathrm{R}$. coriaria, which protects humans against oxidative DNA-damage (Chakrabortya et al., ,2009) is most notable for its antimicrobial and antioxidant activities (Gulmez,Oral and Vatansever ,2006).

Phenolic compounds, which are secondary metabolites in plant materials, are known to be responsible for antioxidant effect. Recent epidemiological studies have strongly suggested that consumption of certain plant materials may reduce the risk of chronic diseases related to oxidative stress on account of their antioxidant activity and promote general health benefits (Halliwell ,1997).

On the other hand, in the food industry, antioxidants are used to retard the oxidative degradation of fats by inhibiting the formation of free radicals. Synthetic antioxidants, such as butylated hydroxyanisole (BHA), butylated hydroxytoluene (BHT) and propylgallate (PG) are widely used; however, the use of synthetic antioxidants in food products is being questioned (Branen, 1975) and Takajashi and Hiraga ,1978). Consumers have also become more cautious about the nutritional quality and safety of food additives. In response to the growing consumer demand, investigations on antioxidants from natural sources have gained interest (Pokorny, 1991).

Fruits and vegetables are the main sources of phenolic compounds in human diet. Other sources, such as grains, herbs and spices, also have received particular attention as sources of antioxidants (Hannum ,2004). The Mediterranean diet is particularly rich in spices. Sumac is one example, which is widely used in Turkey and the Middle East. The fruits are red colored and contain one seed. It's dried and ground leaves have been used as a tanning agent due to their high tannin content (Nakatani ,2000).

Previous phytochemical studies of this plant reported that its leaves contained flavones, tannins, anthocyanins, and organic acids (Karimdzhanov and Ismailov ,1997). However, it is the fruit of the plant that is typically consumed as spice after drying and grinding. Other reports indicated that sumac has antimicrobial activity with limited information on its antioxidant activity 
and potential as a new source of antioxidative substances (Candan and Sokmen ,2004).

Autoxidation and lipolysis are responsible for off flavors and chemical spoilage in lipid containing foods and the products formed via these reactions are potentially toxic (Papadopoulou and Roussis, 2000). Antioxidants play an important role in preventing un desirable changes in flavor and nutritional quality of foods (Zielinski, Kozlowska, 2008).

The oxidative stability of oils and fats may be influenced by many factors, such as light, metal ions, temperature, enzymes and oxygen. The addition of antioxidants to the oil helps to prevent or decrease oil oxidation (Milos et al., 2000). During the last few decades an intensive testing of the safety of synthetic food additive has been carried out and many of them have been found to possess some toxic activity. Hence, the use of natural antioxidants having several functions (reducing agent, free radical scavengers, and potential complexers of prooxidant metals) is becoming a trend in both research and industrial application (Ozcan ,2000)

Canola oil emerged as recommendable dietary oil, which is rich in oleic acid similar to olive oil and with low levels of saturated fatty acids as compared to other vegetable oils. Moreover, compared to olive oil, canola oil contains higher levels of linoleic acid, which has a hypocholesterolemic potential (Hunter , 1990) and diets enriched with canola oil reduced total cholesterol, LDL cholesterol and apoB 100 in humans as compared to safflower oil (Wardlaw et al., 1991).

In addition canola oil has been recommended because it contains high levels of a-linolenic acid; marine sources of linolenic acid as well as vegetable sources have been shown to decrease cytokines which act as cellular mediators in the pathology of atherosclerosis in human and in mice (Mortensen $\boldsymbol{e t}$ al., 1992).

Canola oil was also found to be antithrombic, and had the ability to decrease platelet aggregation. It contains a lower ratio of n- 6 to $n-3$ fatty acids which may allow for better conversion of linolenic acid to eicosapentenasic acid (EPA) known to decrease serum cholesterol in rats. Other benefits for canola oil include its ability to reduce the likelihood of a transient ischemic event that may lead to life threatening cardiac arrhythmia (McLennan and Dallimore ,1995).

Rice bran oil (RBO) contains an unusually high content of unsaponifiables (up to 4.4\%), at a level which is several times greater than most other vegetable oils. The unsaponifiables of RBO are composed of plant sterols (43\%), 4-methyl sterols (10\%), triterpene alcohols (29\%) and less polar components such as squalene or tocotrienols (19\%). In addition, RBO contains up to $20 \%$ saturated fatty acids and approximately equal amounts of 
polyunsaturated (40\%) and monounsaturated fatty acids (40\%), a fatty acid profile quite different from other often-utilized hypocholesterolemic vegetable oils (Helrich ,1990).

Only a little is known about the antioxidative activity of methanolic extract of sumac on oil stabilizing (Ozcan and Akgul ,2000). The aime of this study was to determine the antioxidants activity of sumac extract at various concentrations on rice bran oil \& canola oil stored at $65^{\circ}$.C, In addition determine the fatty acid and rancidity of fats.

\section{Materials:}

\section{Materials and Methods}

\section{Source of samples:}

Syrian sumac powder was collected in May 2011 from local market in Egypt.

Rice bran oil and Canola oil were purchased from a local market as follow:

Rice bran oil: produced by Coagro Company in Thailand.

canola oil : produced by Smucker company in U.S.A.chemicals and reagents were obtained from the Egyptian international center for import, the agent of ( sigma Aldrich Co. USA) .

\section{Extract preparation:}

Plant material $(10 \mathrm{~g})$ was extracted with petroleum ether using a Soxhlet apparatus for $8 \mathrm{~h}$. After drying, defatted plant material $(3 \mathrm{~g})$ was extracted with $40 \mathrm{~mL}$ of $70 \%$ (v/v) aqueous methanol in a shaker bath set at 40 _C for $30 \mathrm{~min}$ and filtered. This extraction step was repeated three times using the same batch of starting material. The filtrates were combined and methanol was evaporated at $40 \_\mathrm{C}$ using a rotavapor until dryness (extract 1). The solid residue was dissolved in $75 \mathrm{~mL}$ of water and extracted with $75 \mathrm{~mL}$ ethyl acetate three times. The ethyl acetate phases were combined and evaporated under vacuum at 40 _C using a rotavapor until dryness (extract 2) (Gamez-Meza et al., 1999).

\section{Assessment of antioxidant activity:}

The oils samples (40 $\mathrm{g}$ each) were placed in open $50 \mathrm{ml}$ beakers in triplicate. Extract was indirectly melted at $40^{\circ} \mathrm{C}$ in a water bath and added to natural canola and rice bran oil in $10 \times 100 \mathrm{~mm}$ open beakers at $1.0 \%, 3.0 \%$ and $5.0 \%(\mathrm{w} / \mathrm{w})$ and dissolved by simple agitation. All samples of $40 \mathrm{~g}$ each were stored at $65{ }^{\circ} \mathrm{C}$ in the dark. The antioxidant activities of substances were evaluated by determining peroxide value (PV) at definite time intervals according to Method Cd 8-53 of the American Oil Chemists' Society. The inhibition rate of autoxidation was performed using the following formula $\mathrm{I}=(\mathrm{M}-\mathrm{L}) \div \mathrm{M} \mathrm{X} 100$

Where $\mathrm{I}=$ inhibition $(\%), \mathrm{M}=\mathrm{PV}$ of control at the same time $(\mathrm{Meq} / \mathrm{kg})$, and $\mathrm{L}=$ $\mathrm{PV}$ of tested samples at the same time (Meq/kg) (Duzgunes et al., 1987). 


\section{Methods:}

\section{Chemical Analysis:}

\section{Rancidity of Fats:}

Saponification number, acid value and peroxide value were determined in the Central Laboratory, National Nutrition Institute, Cairo. Egypt. According to the method of (AOAC, 2000).

\section{Fatty Acid:}

The fatty acids compositions of the oil samples were analyzed using Gas Liquid Chromatography Trace GC Ultra available at the Central Laboratory, National Nutrition Institute, Cairo. Egypt. According to the method of (AOAC, 2000).

\section{Proximate Composition:}

Sumac sample was analyzed for moisture, ash, crude protein, fat, carbohydrates and fiber contents using the methods described by (AOAC ,1990).

\section{Active Groups of Herbies :}

Active group of powder dried of Syrian sumac was analysis by $\{($ Nicolet 6700) inverred (IR instrument) $\}$ in faculty of science Ain Shams University central laboratory in July 2011 according to (John ,1978, john and sems ,1976).

\section{Statistical analysis:}

The obtained data were statistically analyzed according to SAS (1996). Data are expressed as means + SD. Effect Of Syrian Sumac Extract was determined by one-way analysis of variance (ANOVA) procedure (Steel and Torrie, 1980).

\section{Chemical analysis:}

\section{$\underline{\text { Results And Discussions }}$}

The results in Table (1) indicated that the mean gross rancidity of fats of rice bran oil was $1 \%, 3.7 \%, 205 \%$ and $0.8 \%, 5.58 \%, 202 \%$ of canola oil for acid value, peroxide value and saponification respectively. These results was disagreement with (Perzybylski and Mag ,2002) who studied the composition and properties of vegetable oils used in food technology and reported that The rancidity of RBO was $0.9 \%, 97-115 \%$ and $165-200 \%$ for acid value, iodine number and saponification number, respectively.

Table (1): Rancidity of fats of Rice bran and Canola oils

\begin{tabular}{|c|c|c|}
\hline $\begin{array}{c}\text { Rancidity of fats } \\
\text { \% }\end{array}$ & RBO & Canola \\
\hline AV & 1.0 & 0.8 \\
\hline PV & 3.7 & 5.58 \\
\hline
\end{tabular}




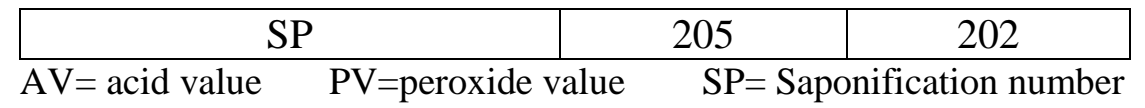

The present data (Table 2) indicated that the percentage of saturated fatty acids Palmitic acid (C16:0) and Arachidic acid (C20:0) of rice bran oil were $16.73 \%$ and $11.70 \%$, respectively which were found to be higher than that of canola oil $(3.93 \%$ and $12.64 \%$ respectively). On the other hand, the percentage of Poly Unsaturated Fatty Acid of Linoleic acid (C18:2) and Linolenic acid (C18:3) of rice bran oil (30.17\% and $2.14 \%$, respectively) which were found to be lower than the canola oil (30.71\% and $15.40 \%$ respectively).

Table (2): Fatty acids composition of rice bran oil and canola oil

\begin{tabular}{|c|c|c|c|}
\hline \multirow{4}{*}{ Type of Fatty acids } & $\begin{array}{c}\text { Fatty acids } \\
\text { (Relative) }\end{array}$ & Rice Oil & $\begin{array}{c}\text { Canola } \\
\text { Oil }\end{array}$ \\
\cline { 2 - 4 } & Caprylic acid & 0.04 & $\%$ \\
\hline \multirow{4}{*}{ Saturated Fatty Acids } & Capric acid & - & 0.08 \\
\cline { 2 - 4 } & Lauric acid & 0.05 & - \\
\cline { 2 - 4 } & Myristic acid & 2.01 & 0.20 \\
\cline { 2 - 4 } & Palmitic acid & 16.73 & 3.93 \\
\cline { 2 - 4 } & $\begin{array}{c}\text { Arachidic } \\
\text { acid }\end{array}$ & 11.70 & 12.64 \\
\hline $\begin{array}{c}\text { Mono Unsaturated } \\
\text { Fatty Acid }\end{array}$ & $\begin{array}{c}\text { Oleic acid } \\
\text { Poly Unsaturated Fatty } \\
\text { Acid }\end{array}$ & 37.16 & 36.40 \\
\cline { 2 - 4 } & Linoleic acid & 30.17 & 30.71 \\
\hline \multirow{2}{*}{$\begin{array}{c}\text { Linolenic } \\
\text { acid }\end{array}$} & 2.14 & 15.40 \\
\cline { 2 - 4 } & Erucic acid & - & 0.53 \\
\hline \multicolumn{2}{|c|}{ Total saturated fatty acids(T.S) } & 30.53 & 17.01 \\
\hline \multicolumn{2}{|c|}{ Total unsaturated fatty acids(U.T.S) } & 69.47 & 82.99 \\
\hline
\end{tabular}

These results were agreement with (Rukmini and Raghuram ,2010) who demonstrated that RBO contained oleic acid (38.4\%), linoleic acid $(34.4 \%)$, and linolenic acid (2.2\%) as unsaturated fatty acids, and palmitic $(21.5 \%)$ and stearic $(2.9 \%)$ acids as saturated fatty acids. On the other hand, these results were disagreement with (BABA et al.; 2000) who reported that canola oil contained Palmitic (16:0) (4.4\%), Stearic (18:0) (1.9\%), Oleic (18:1) (62.4\%), Linoleic (18:2) (21.3\%) and Linolenic (18:3) (9.9\%).

Table (3): Chemical composition of Syrian sumac powder

\begin{tabular}{|c|c|}
\hline $\begin{array}{c}\text { Chemical composition } \\
(\mathbf{g}) / \mathbf{k g}\end{array}$ & Syrian sumac \\
\hline protein & $5 \pm 1.56$ \\
\hline fat & $11.65 \pm 2.57$ \\
\hline
\end{tabular}




\begin{tabular}{|c|c|}
\hline Carbohydrates & $73.15 \pm 1.98$ \\
\hline moistures & $6.4 \pm 0.45$ \\
\hline Ash & $3.8 \pm 2.43$ \\
\hline Fiber & $19.76 \pm 1.54$ \\
\hline
\end{tabular}

The present data (Table 3) indicated the nutrient values of dried Syrian sumac were $5,11.65,73.15,6.4,3.8$ and 19.76 of protein, fats, carbohydrates, moistures, ash, and fiber, respectively. These results were agreement with (Akinci et al., 2004) which compared between Syrian and Chinese sumac the results were the Chinese sumac showed a higher content in protein, fat, fiber and ash. The present results showed that the Syrian sumac can be considered as potential source of dietary fiber which is helpful in alleviating gastrointestinal disorders.

Active Groups of Syrian sumac:

Table (4): Active Groups of Syrian sumac powder

\begin{tabular}{|l|l|}
\hline \multicolumn{1}{|c|}{ peak } & \multicolumn{1}{c|}{ Function group } \\
\hline 1053,1096 & Bending $\mathrm{O}-\mathrm{C}$ alcohol or ester \\
\hline 1320 & Bending $\mathrm{OH}$ \\
\hline 1447 & Bending $\mathrm{CH}$ \\
\hline 1616 & yC=C \\
\hline 1738 & yC $=\mathrm{O}$ of ester \\
\hline 2855,2926 & yC $=\mathrm{H}$ for $\mathrm{CH}_{2}$ and $/$ or $\mathrm{CH}_{3}$ \\
\hline 3354 & VOH phenolic (or alcoholic) \\
\hline
\end{tabular}

The results present in the table (4) showed that Compound may be polycyclic aliphatic compound containing ester group and $=\mathrm{C}=\mathrm{C}=$

Table (5): Active Groups of dried PE sumac extract as indicated by chromatograph

\begin{tabular}{|l|l|}
\hline \multicolumn{1}{|c|}{ peak } & \multicolumn{1}{|c|}{ Function group } \\
\hline 1036 & $\begin{array}{l}\text { OH bending or O-C stretching } \\
\text { for 1 er ALC. }\end{array}$ \\
\hline 1101 & $\begin{array}{l}\text { OH bending or O-C stretching } \\
\text { for 2 }{ }^{\text {nd }} \text { ALC. }\end{array}$ \\
\hline 1216 & y O-C of ester (stretching) \\
\hline 1322 & $\begin{array}{l}\text { OH bending or C-O stretching } \\
\text { of 1 er AL. }\end{array}$ \\
\hline 1394 & CH bending \\
\hline 1623 & Y C =C for stretching \\
\hline 1732 & $\begin{array}{l}\text { Y C=O of ester group } \\
\text { (stretching) }\end{array}$ \\
\hline 2856 & Y C -H for stretching \\
\hline 2928 & \\
\hline
\end{tabular}


\begin{tabular}{|l|l|}
\hline 3422 & YOH \\
\hline
\end{tabular}

The results present in the table (5) showed that Compound containing ester group and $=\mathrm{C}=\mathrm{C}=$ and $\mathrm{OH}$ group. 


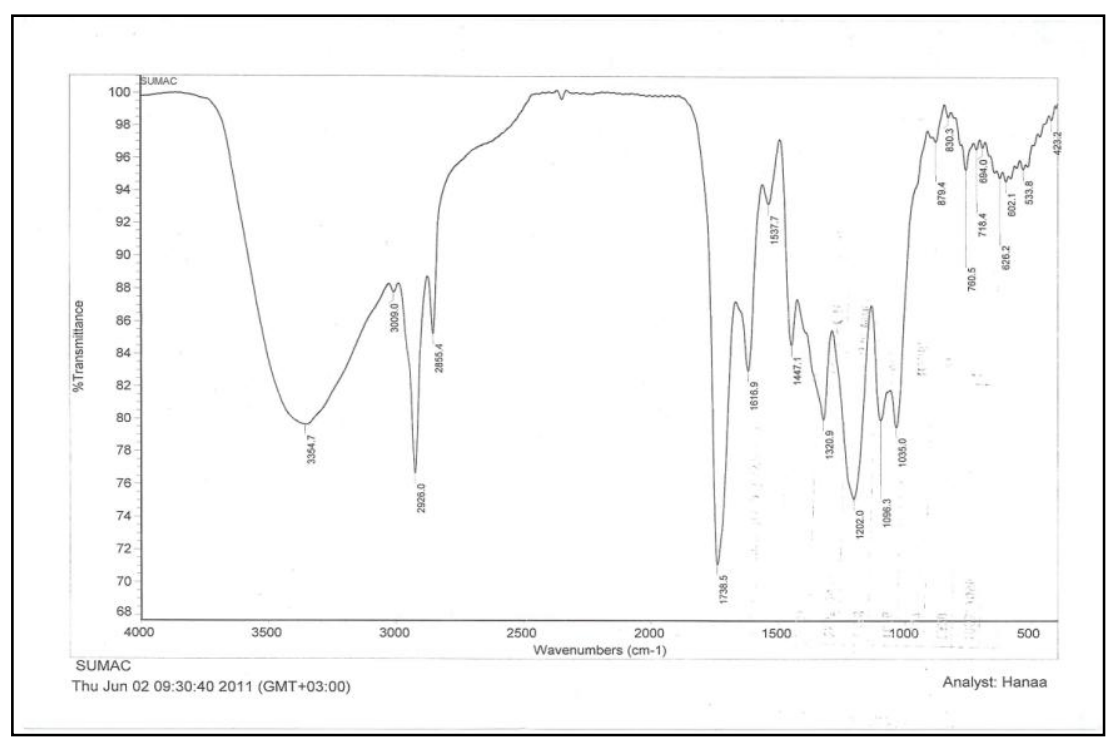

Figure (1): Active Groups of Syrian sumac powder Figure (2): Active Groups of dried PE sumac extract

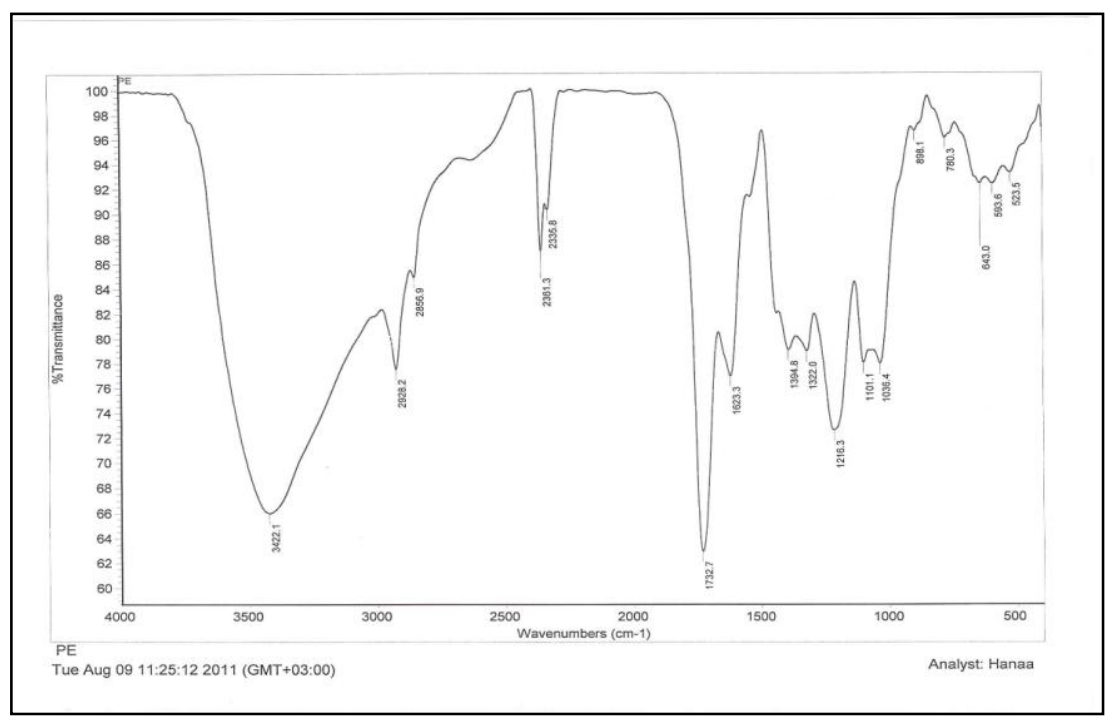

The present data (fig. 1 and 2) showed that the phenolic compounds found in sumach extract by extraction of petroleum ether this means it's not found in the dry sumach.

Table (6) Peroxide Value of Rice Bran Oil and Canola Oil up on storage period for 35 days at $65^{\circ} \mathrm{C}$ 


\begin{tabular}{|c|c|c|c|c|c|}
\hline \multirow{2}{*}{$\begin{array}{c}\text { Conc. } \\
(\%)\end{array}$} & $\mathbf{7}$ & $\mathbf{1 4}$ & $\mathbf{2 1}$ & $\mathbf{2 8}$ & $\mathbf{3 5}$ \\
\cline { 2 - 6 } & \multicolumn{5}{|c|}{ Days } \\
\hline $\begin{array}{c}\text { Control } \\
\text { Rice }\end{array}$ & $14.18 \pm 1.65$ & $45.31 \pm 0.54$ & $50.49 \pm 2.49$ & $81.32 \pm 1.48$ & $112.31 \pm 4.56$ \\
\hline E o.1 & $11.6 \pm 1.15$ & $30.49 \pm 1.34$ & $35.21 \pm 1.37$ & $37.9 \pm 2.04$ & $43.3 \pm 3.29$ \\
\hline E o.3 & $5 \pm 1.12$ & $28.6 \pm 1.76$ & $34.5 \pm 0.52$ & $43.23 \pm 2.45$ & $60.69 \pm 1.95$ \\
\hline E o.5 & $9 \pm 2.43$ & $12.04 \pm 2.50$ & $15.22 \pm 3.65$ & $17.3 \pm 1.50$ & $21.46 \pm 1.59$ \\
\hline $\begin{array}{c}\text { Control } \\
\text { Canola }\end{array}$ & $13.03 \pm 1.07$ & $23.2 \pm 1.59$ & $43.67 \pm 1.71$ & $56.28 \pm 1.48$ & $64.32 \pm 1.50$ \\
\hline E o.1 & $8 \pm 1.24$ & $15.6 \pm 0.59$ & $19.5 \pm 1.07$ & $23.22 \pm 4.51$ & $29.83 \pm 0.88$ \\
\hline E o.3 & $7.8 \pm 0.68$ & $16.28 \pm 2.54$ & $22.37 \pm 0.45$ & $11.63 \pm 2.58$ & $28.74 \pm 4.62$ \\
\hline E o.5 & $7.8 \pm 2.43$ & $15.25 \pm 1.93$ & $24.49 \pm 3.94$ & $20.11 \pm 0.38$ & $26.72 \pm 2.69$ \\
\hline
\end{tabular}

The results present in the table (6) showed that after 7 to 35 days of storage the peroxide value of rice bran oil and canola oil added to the extracts of sumach were lower than the control sample. This means that the sumac extract the content on the active groups in preventing autoxidation of rice bran oil and canola oil, therefore the increase in concentration of sumac extract increases the antioxidative effect. Extract at $0.5 \%$ in the rice bran oil after 14 to 35 days of storage had better antioxidant activity $(12.04 \%, 15.22 \%, 17.3 \%$ and $21.46 \%$ ) than the control sample. On the other hand, extract at $0.5 \%$ in the canola oil had better antioxidant activity except for after 14 and 35 days of storage. (Musa Özcan, 2004) who proved that the antioxidant effect of all extracts of Rosemary, Sage, and Sumac were low compared with that of butylated hydroxytoluene. Sumac extract exhibited the most antioxidant effect compared with other individual extracts. Of blends, the most effective ones were sage plus sumac combinations. Sumac extract is also promising as a source of natural antioxidants.

According to the data of Table (7) the rate of inhibition of autoxidation in the rice bran oil increases by increasing the concentration of extracts of sumach after 7 into 21 days of storage (E 0.1: 18.19\%, 32.71\% and 30.265 But E $0.5: 36.53 \%, 73.43 \%$ and $69.86 \%$ ).

\section{Table (7) Inhibition Rate (\%) of Autoxidation by extract of Syrian sumac}

\begin{tabular}{|c|c|c|c|c|c|c|c|c|c|c|}
\hline \multirow{2}{*}{$\begin{array}{c}\text { Conc. } \\
(\%)\end{array}$} & \multicolumn{10}{|c|}{ Days } \\
\cline { 2 - 11 } & \multicolumn{2}{|c|}{$\mathbf{7}$} & \multicolumn{2}{|c|}{$\mathbf{1 4}$} & \multicolumn{2}{|c|}{21} & \multicolumn{2}{|c|}{28} & \multicolumn{2}{|c|}{35} \\
\cline { 2 - 10 } & $\mathrm{E}$ & $\mathrm{N}$ & $\mathrm{E}$ & $\mathrm{N}$ & $\mathrm{E}$ & $\mathrm{N}$ & $\mathrm{E}$ & $\mathrm{N}$ & $\mathrm{E}$ & $\mathrm{N}$ \\
\hline
\end{tabular}




\begin{tabular}{|c|c|c|c|c|c|c|c|c|c|c|}
\hline \multicolumn{10}{|c|}{ Rice Bran Oil } \\
\hline E o.1 & 18.19 & 0.227 & 32.71 & 0.409 & 30.26 & 0.378 & 53.39 & 0.667 & 61.45 & 0.768 \\
\hline E o.3 & 64.74 & 0.809 & 36.88 & 0.461 & 31.67 & 0.396 & 46.84 & 0.586 & 45.96 & 0.575 \\
\hline E o.5 & 36.53 & 0.457 & 73.43 & 0.918 & 69.86 & 0.873 & 78.73 & 0.984 & 80.89 & 1.011 \\
\hline \multicolumn{10}{|c|}{ Canola Oil } \\
\hline E o.1 & 38.60 & 1.448 & 32.76 & 1.229 & 55.35 & 2.076 & 58.74 & 2.203 & 53.62 & 2.011 \\
\hline E o.3 & 40.14 & 1.505 & 29.83 & 1.119 & 48.77 & 1.829 & 79.34 & 2.975 & 55.32 & 2.075 \\
\hline E o.5 & 40.14 & 1.505 & 34.27 & 1.285 & 43.92 & 1.647 & 64.27 & 2.410 & 58.46 & 2.192 \\
\hline
\end{tabular}

E= Inhibition Rate of extract Rate of total natural antioxidants

$\mathbf{N}=$ Inhibition

On the other hand, the rate of inhibition of autoxidation in the canola oil was higher after 14 and 35 days of storage in the E $0.5 \%$ (34.27\% and 58.46) but it was lower after 7, 28 and 35 days of storage in the E $0.1 \%$ (38.60\%, $58.74 \%$ and $53.62 \%$ ). The data of the same table also indicated that the percentage of inhibition of autoxidation in the rice bran oil due to the presence of total natural antioxidants was $1.25 \%$ but it was $3.75 \%$ in the canola oil. These results were agreement with (Kosar et al., 2006) who proved that the extracts of sumach and fractions showed moderate lipid peroxidation inhibition effect compared with the synthetic antioxidants. The findings demonstrate that sumac can be used as a natural antioxidant.

\section{Conclusion}

The results showed that different concentrations of sumac extract a strong influence on the inhibition of fat. The sumac extract is one of the articles of natural antioxidants that prevent oxidation of fatty food

\section{$\underline{\text { References }}$}

Akinci, I.; F. Ozdemir, A.; Topuz, O. Kabas and M. Canakci, (2004). Some physical and nutritional properties of juniperus druoacea fruits. J. Food Eng., 65:325-331.

American oil chemists society (1994). Official methods and recommended practices, 4 th.

A.O.A.C. (1990). "Official Methods of Analysis" Association of Official Analytical Chemists. Arlington, Vergenia, D.C., U.S.A.

A.O.A.C. (2005). "Official Methods of Analysis" Association of Official Analytical Chemists. Arlington, Vergenia, D.C., U.S.A. 
Branen, A.-L. (1975). Toxicology and biochemistry of butylated hydroxyanisole and butylated hydroxytoluene. Journal of the American Oil Chemists' Society, 52, 59-63.

Candan, F. and Sokmen, A. (2004). Effects of Rhus coriaria L. (Anacardiaceae) on lipid peroxidation and free radical scavenging activity. Phytotherapy Research, 18, 84-86.

Chakrabortya, A.; Ferka, F.; Simi_c, T.; Brantnerb, A.; Du_sinská, M. and Kundid, M. (2009). DNA-protective effects of sumach (Rhus coriaria L.), a common spice: results of human and animal studies. Mutation Research, 661, 10e17.

Duzgunes, O.; Kesici, T.; Kavuncu, O. and Gurbuz, F. (1987). Methods of Research and Experiment: the statistical Methods - II (Arastirma ve Deneme Metotlari). Ankara Univ. Agric. Fac. Publ. No.1021 in Turkish.

Erichsen-Brown, C. (1989). Medicinal and other uses of North American plants: A historical survey with special reference to the Eastern Indian tribes. New York, USA: Dover Publications.

Gamez-Meza, N.; Noriega-Rodriguez, J. A.; Medina-Juarez, L. A.; OrtegaGarcia, J.; Cazarez-Casanova, R. and Angulo-Guerrero, O. (1999). Antioxidant activity in soybean oil of extracts from Thompson grape bagasse. Journal of the American Oil Chemists' Society, 76, 14451447.

Gulmez, M.; Oral, N. and Vatansever, L. (2006). The effect of water extract of sumac (Rhus coriaria L.) and lactic acid on decontamination and shelf life of raw broiler wings. Poultry Science, 85, 1466e1471.

Halliwell, B. (1997). Antioxidants and human disease: a general introduction. Nutrition Reviews, 55, 544-552.

Hannum, S. M. (2004). Potential impact of strawberries on human health: a review of science. Current Reviews in Food Science and Nutrition, 44, $1-17$.

Helrich, K. Ed (1990). Nitrogen in meat Kjeldahl method. In: Official Methods of Analysis of the AOAC International. 15" Ed; Association of Official Analytical Chemists, Inc. Virginia, USA; p. 935.

Hunter, J.E. (1990). n-3 fatty acids from vegetable oils. Am J Clin Nutr; 51: 809-814.

John, W. and Sems ., (1976). Modern methods of chemical analysis. (4): 341349.

John, R. Dyer. (1978). Application of absorption spectroscopy of organic compounds. New Delhi- 110001.

Karimdzhanov, A. K. and Ismailov, A. I. (1997). Anthocyanins and organic acids of the fruits of some species of sumac. Chemistry of Natural Compounds, 33, 209. 
Kosar, M. ; Bozan, B.; Temelli, F. and Baser, K.H.C. (2007). Antioxidant activity and phenolic composition of sumac (Rhus coriaria L.) extracts. Food Chemistry Volume 103, 3, P. 952-959.

McLennan, P.L. and Dallimore, J.A. (1995). Dietary canola oil modifies myocardial fatty acids and inhibits cardiac arrhythmias in rats. J Nutr; 125(14): 1003-1009).

Milos, M. Mastelic, J. and Jrkovic, I. (2000). Chemical composition and antioxidant effect of glycosidically bound volatile compounds from (Origanum Vulgar L. ssp. Hirtum) food chem. 71:79-83.

Mortensen, A.; Espensen, P.L.; Hansen, B.F. and Ibsen, P. (1992). The influence of dietary olive oil and margarine on aortic cholesterol accumulation in cholesterol-fed rabbits maintained at similar plasma cholesterol level. Atherosclerosis ; 96(2-3): 159-170.

Musa Özcan (2004): Antioxidant Activities of Rosemary, Sage, and Sumac Extracts and Their Combinations on Stability of Natural Peanut Oil. Journal of Medicinal Food. October 2003, 6(3): 267-270.

Nahla Hwalla Baba, Ph.D; Zeina Ghossoub, M.Sc and Zuheir Habbal, Ph.D. (2000). differential effects of dietary oils on plasma lipids, lipid Peroxidation and adipose tissue lipoprotein lipase activity in rats.Nutrition Research, Vol. 20, No. 8, pp 1 I I3- I 123,

Nakatani, N. (2000). Phenolic antioxidants from herbs and spices. BioFactors, 13, 141-146.

Ozcan, M. (2000). Use of propolis extract as a natural antioxidant for plant oil. Grasas Y Aceites 4:251- 253.

Ozcan, M. and Akgul, A. (2000). Antioxidants activity of extracts and essential oils from Turkish spices on sunflower oil. Acta aliment 24:8190.

Papadopoulou, D. and Roussis, I.G. (2000). Inhibition of corn oil oxidation by thiols. Ital J food sci 2:239-242.

Perzybylski, R. and Mag, T. (2002). Canola/rapeseed oil. In: Gunstone DF (ed). Vegetable oils in food technology: composition, properties and uses. Blackwell Publishing Ltd USA. pp 98- 127.

Pokorny, J. (1991). Natural antioxidants for food use. Trends in Food Science and Technology, 2, 223-227.

Rayne, S. and Mazza, G. (2007). Biological activities of extracts from sumac (Rhus spp.): a review. Plant Foods for Human Nutrition, 62, $165 \mathrm{e} 175$.

Rukmini, C. and Raghuram, T.C. (2010). Nutritional and biochemical aspects of the hypolipidemic action of rice bran oil. J Am Coll Nutr. Dec;10(6):593-601.

Steel, R.G. and Torrie, J.A. (1980). Principles and procedures of statistics. .McGraw-Hill Book Co., New York. 
Takajashi, O. and Hiraga, K. (1978). Effects of low levels of BHT on the prothrombin index of male rats. Food Cosmetology and Toxicology, $16(5), 475-477$.

USDA (United States Department of Agriculture). (2007). Germplasm resources information network. Beltsville, MD, USA: Agricultural Research Service.

Van Wyk, B. E. and Wink, M. (2004). Medicinal plants of the world. Portland, OR, USA: Timber Press.

Wardlaw, G.M.; Snook, J.T.; Lin, M.C.; Puanges, M.A. and Kwon, J.S. (1991). Serum lipid and apolipoprotein concentrations in healthy men on diets enriched in either canola oil or safflower oil. Am J Clin Nutr; 54: 104- 110.

Zielinski, H. and Koziowska, H. (2008). Antioxidants activity and total phenolic in selected cereal grains and their different morphological fractions. J Agric food chem 2000; 48:88. 


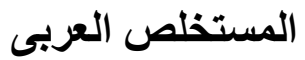

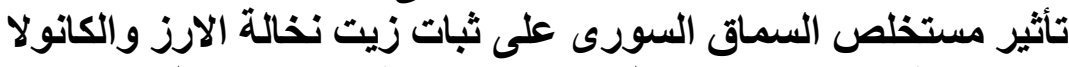

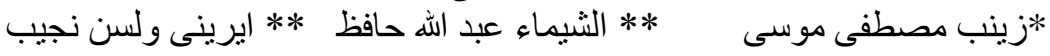 \\ *استاذ مساعد تغذية و علوم أطعمة- قسم الاقتصاد المنزلي- كلية التربية - جامعة عين شمس \\ * مدرس تغذية و علوم أطعمة- قسم الاقتصاد المنزليـ كلية التربية - جامعة عين شمس}

تم اختبار نشاط مضادات الاكسدة بتركيز ات متنو عه من مستخلص السماق على زيت الارز

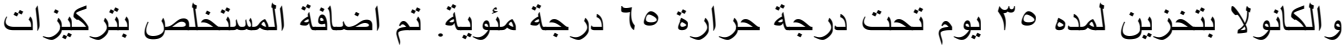

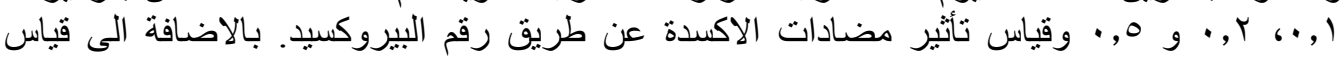

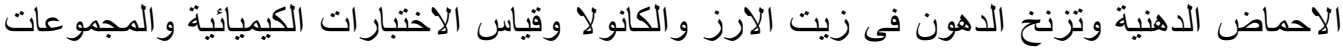

الفعالة فى بودرة السماق.

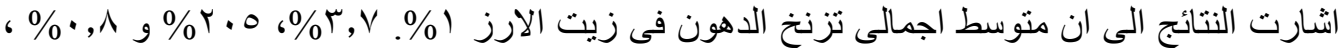

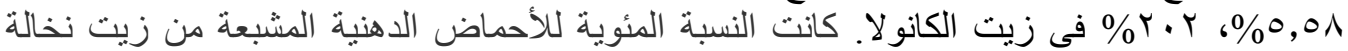

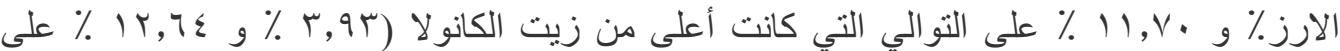

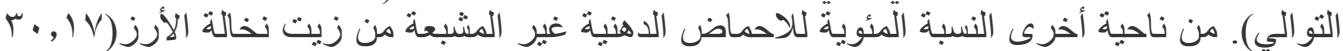

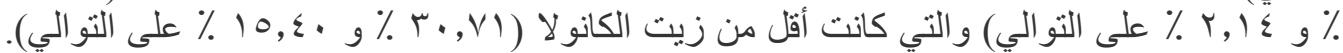

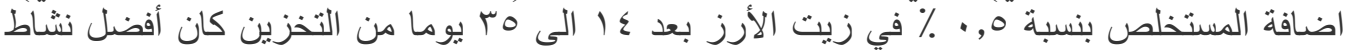

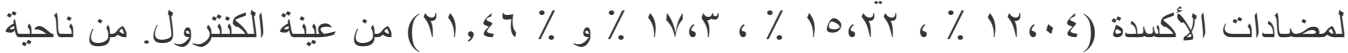

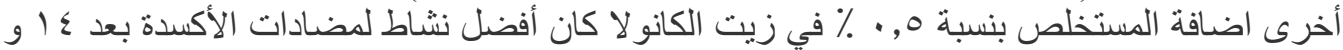

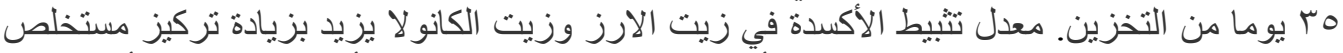

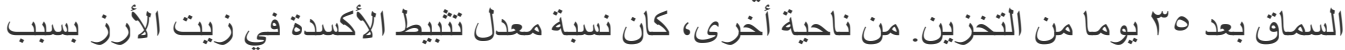

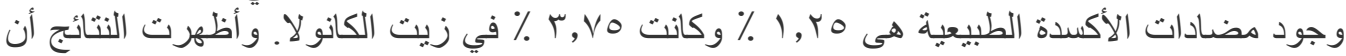

مستخلص السماق يعتبر مصدر لمضادات الإكسات الاكسدة الطبيعية.

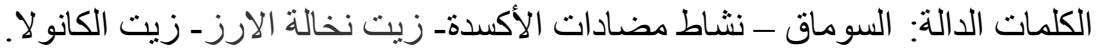

